\title{
ANALYSIS OF LAND EROSION DUE TO MINING OF CLAY MATERIAL IN SIDOREJO VILLAGE, SLEMAN DISTRICT, YOGYAKARTA
}

\author{
Delia Ximenes Amaral BELO ${ }^{1}$ (D), Rika ERNAWATI ${ }^{(1 D}$, Tedy Agung CAHYADI ${ }^{3}$ (D), \\ NURKHAMIM ${ }^{4}$ (D), Nur Ali AMRI ${ }^{5}$ (D)
}

DOI: 10.21163/GT_2020.151.20

\begin{abstract}
:
Mining can cause changes in the shape of landmasses and lead to erosion. Erosion results from the interaction of climate, soil, topography, vegetation and human activity on natural resources. The purpose of this study is to analyze the level of soil erosion and provide direction for land conservation priorities. The analytical method using the Universal Soil Loss Equation (USLE) method. USLE has five parameters is rainfall erosivity factor, Soil erodibility factor, terrain factors: the slope length and slope steepness, land cover and management factor, Conservation practices factor. The soil erosion rate is composed of five classes; very low, low, moderate, heavy and very heavy. The final results of this study based on the danger level of soil erosion with analysis overlay the map could indicate that erosion very heavy consists of $30 \%$, heavy $5 \%$, moderate $25 \%$, low $10 \%$ and very low $30 \%$. Priority for land conservation is based on the land conservation index table which is from very heavy erosion to very low erosion. To minimize current erosion rates by adopting a vegetative method.
\end{abstract}

Key-words: Soil Erosion, Mining, Clay, USLE, Sleman

\section{INTRODUCTION}

Mining activities carried out both mechanically and traditionally always have impacts, namely positive and negative impacts. The positive impact is that the extracted minerals can be utilized to meet human needs in building infrastructure and the negative impact of mining activities is the occurrence of landform changes in the mining area where the changes in landforms generally result in erosion and soil mass movements (Indonesianto, 2008). Erosion is a process by which soil and rocks wear out, then transported by natural or anthropogenic agents and deposited elsewhere (Da Cruz et al., 2019); Verheijen et al., 2009), it can pollute water, cause land degradation, reduce soil fertility and increase the loss of organic matter (Cerdan et al., 2010). Soil loss brings concern all over the planet, as it is a source for food production (Abel et al., 2005). Argues that erosion is the erosion of soil from a place that is transported by water or wind to another place (Arsyad,1989). Soil erosion reduces the ability of the soil to hold water due to soft particles organic matter in the soil transported (Rifky et al., 2016).

The erosion process starts from the destruction of the soil as a result of rainwater blows that have greater power than the resistance of the soil, the destruction of soil particles that clog the pores of the soil resulting in decreased soil infiltration capacity so that water flows on the surface of the ground as surface runoff (Asdak,1995).

Erosion depresion by into three, namely empirical models, physical models, and conceptual models. Empirical water is a result of the power (Irimus et al., 2017). Soil

\footnotetext{
1,2,3,4, UPN Veteran Yogyakarta, Faculty of Mineral Technology, 55583 Yogyakarta, Indonesia liabelo@yahoo.com; rika.ernawati@upnyk.ac.id; tedyagungc@upnyk.ac.id Nurkhamim@upnyk.ac.id; Nuraliamri@upnyk.ac.id
} 
erosion models can be classified models are based on important variables obtained from research and observations during the erosion process (Baver, 1972). Methods with empirical models are used, for example, the Universal Soil Loss Equation (USLE), which emerged in the late 1970s (Wischmeier \& Smith, 1978) in the United States, but it is widely used in Brazil. This method presents great accuracy, as considers soil type, soil morphology, rainfall, cultivation practices and management, allows quantification and regionalization of the area with higher risk of erosion (Wischmeier \& Smith, 1978; Bertoni, 2005; 2012).

\section{STUDY AREA AND DATA}

Sidorejo Village, Godean Sub-District, Sleman District, Yogyakarta was used as the study area. The Sleman region was a tropical climate and is located between the ranges of coordinates; longitude: $110^{\circ} 16^{\prime} 4^{\prime \prime} \mathrm{E}$ and $110^{\circ} 16^{\prime} 3^{\prime \prime} \mathrm{E}$, latitude: $7^{\circ} 44^{\prime} 15^{\prime \prime} \mathrm{N}$ and $7^{\circ} 44^{\prime} 21^{\prime \prime} \mathrm{N}$ Study area is approximately $24 \mathrm{~km}$ the Sidorejo Village, by motocyle taken one hour. In this research, the method used is the survey and testing of soil samples in the laboratory. Field observations (field surveys) are conducted to observe or review conditions around the mining area that are specific to the location that will be used as data collection likes to measurement the slope length and slope steepness help by topographic maps, observation direct for land cover and management factor and conservation practices factor and determine value 6 , and organic matter in order to calculate the value soil erodibility factor. The sampling is done by a random sampling method. The number of sides taken as many as 20 pieces at the clay mine site for primiry data collection can been seen in (Fig. 1) and for map sampling can been seen in (Fig. 2)

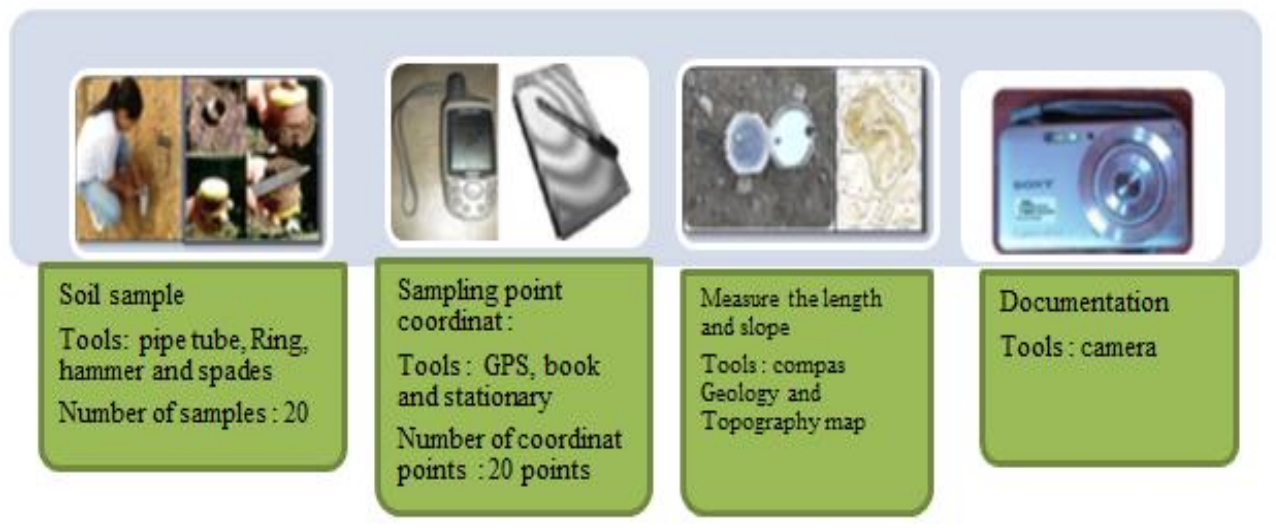

Fig. 1. Primary data (Source: Author).

In this study sampling locations can be divided into three locations, namely the first location in the paddy field area, the second location in the mining area and the third location in the dryland area. Twenty (20) sample points were taken using purposive sampling method. At the first location the number of samples taken was 5 samples, at the second location the number of samples taken was 10 sample points and at the third location the number of samples taken was 5 samples. In Fig. 2 it can be shown that yellow is the first location in the rice field area, brown is the second location in the mine area and dark green is the third location in the dry area. 


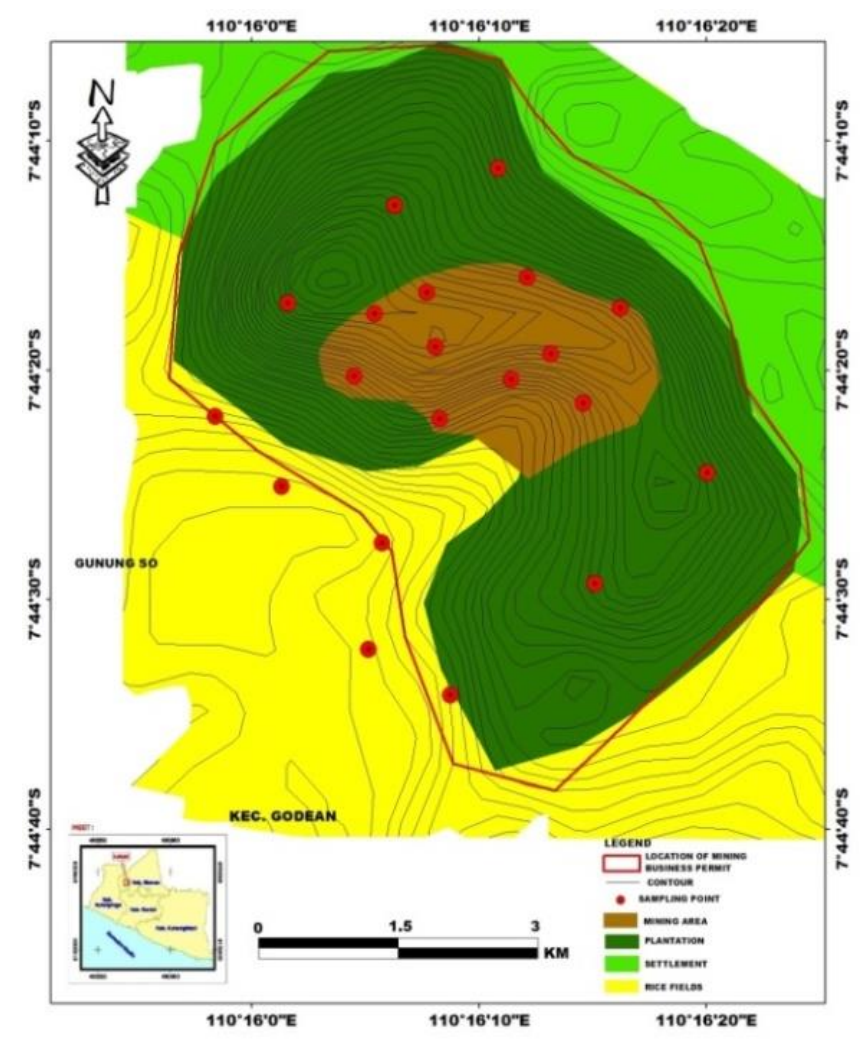

Fig. 2. Sampling Map (Authors).

\section{METHODOLOGY}

In this research used the methods study of literature and survey, to analysis to the soil rete erosion and erosion hazard level use the method Universal Soil Loss Equation (USLE).

\subsection{Analysis Soil Erosion with Method Universal Soil Loss Equation (USLE)}

The USLE model was applied to assess soil erosion in the Sidorejo Village Sleman District, Yogyakarta. The calculation of estimation of erosion rate by the USLE method is to multiply all factors that affect soil erosion (Wischmeier and Smith, 1978). Where the USLE formula can be written as follows;

$$
\mathrm{A}=\mathrm{R} \cdot \mathrm{K} \cdot \mathrm{LS} \cdot \mathrm{C} \cdot \mathrm{P}
$$

where:

$\mathrm{A}=$ The soil erosion rate (tons/ha/ year),

$\mathrm{R}=$ Defined as rainfall runoff erosivity factor ( $\mathrm{MJ} \mathrm{mm} \mathrm{ha/} \mathrm{year})$

$\mathrm{K}=$ Soil erodibility factor $(\mathrm{t}$ ha $\mathrm{MJ} / \mathrm{mm})$

LS = Length and Slope Factor (LS) (unites)

$\mathrm{C}=$ Land cover and management factor (unites)

$\mathrm{P}=$ Stands for conservation practices factor (unites). 
Erosion Hazard Classes are given to each unit of land with a matrix that uses soil solum information and erosion estimates according to USLE formulas. Erosion classified as very low, low, moderate, heave and very heavy can be seen in Table 1. Based on the table, it can classified that the value of erosion is very low $<15$ tons / ha / year, the value of low erosion is 15-60 tons / ha / year, moderate erosion value is 60-180tons / ha / year, the value of erosion is including the heavy category is $180-480$ tons / ha / year and very heavy erosion value is $>480$ tons / ha / year.

Table 1.

Classification of Erosion Hazard Levels.

\begin{tabular}{|c|c|c|}
\hline Class & Erosion hazard level (tons /ha /year) & Category \\
\hline 1 & $<15$ & Very low \\
\hline 2 & $15-60$ & Low \\
\hline 3 & $60-180$ & Moderate \\
\hline 4 & $180-480$ & Heavy \\
\hline 5 & $>480$ & Very heavy \\
\hline
\end{tabular}

Source: Morgan (1974).

\subsection{Conservation Priority Analysis}

Changes in the management and use of land resulted from human activities can increase soil erosion causing irreversible damage to the environment (Fiorio et al.,2016); (Da Silva et al., 2016). The vegetation withdrawal due to the insertion of plantations can increase up to $600 \%$ soil erosion (Chaplot et al., 2005). Conservation priority is given based on the class of erosion hazard level (Ministry of Forestry, 1998). The level of erosion hazard is very heavy, getting the priority means immediately to do land conservation. The conservation priority table is presented in Table 2 .

Table 2.

Conservation Priorities.

\begin{tabular}{|c|c|c|}
\hline Class & Erosion Hazard Class & Category \\
\hline 1 & Very heavy & I \\
\hline 2 & Heavy & II \\
\hline 3 & Moderate & III \\
\hline 4 & Low & IV \\
\hline 5 & Very low & V \\
\hline
\end{tabular}

Source: Ananta (1987).

Based on Table 2 Priorities conservation land for given to the value erosion is very heavy, the second for the heavy erosion, moderate erosion, very low erosion and the last for the low erosion. Conservation priorities land given base on class erosion. For detailed of the research methods can be seen in (Fig. 3). 


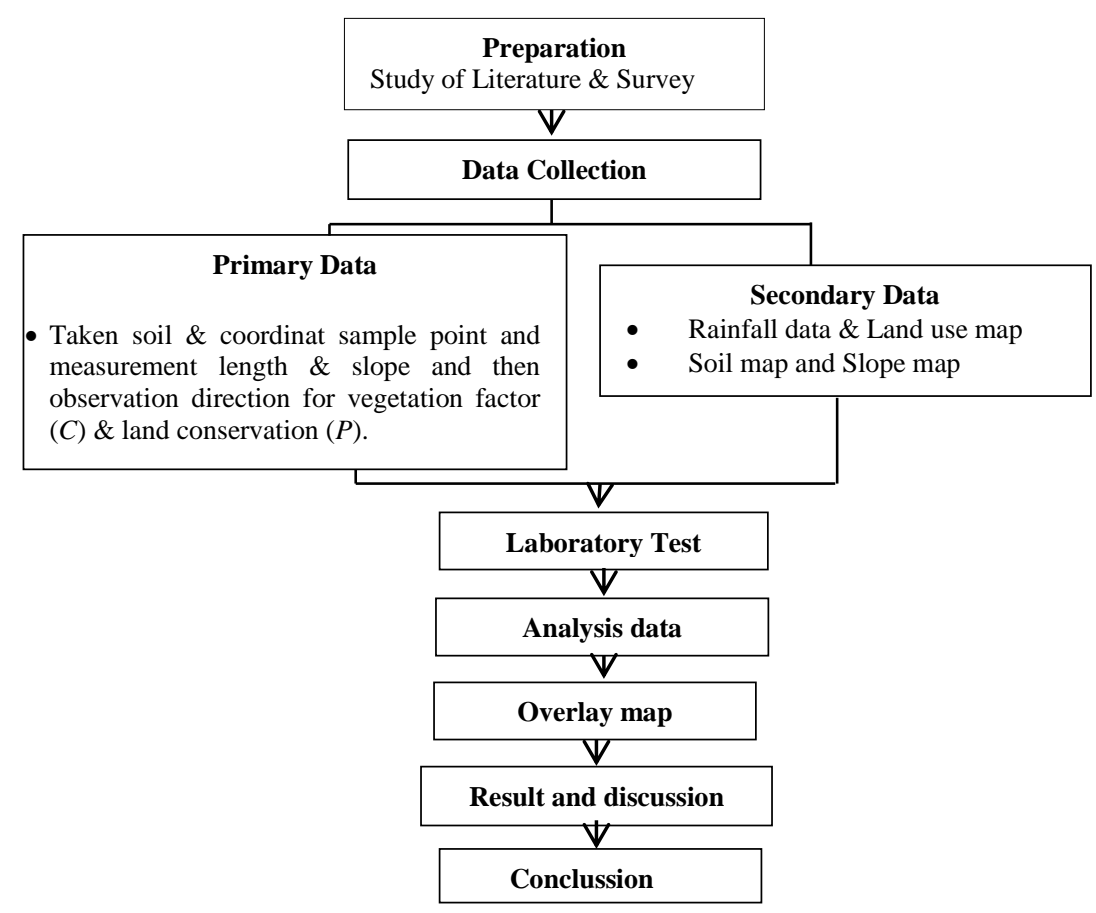

Fig. 3. Methodology Research Flowchart.

\section{RESULTS AND DISCUSSIONS}

\subsection{Analysis of Soil Erosion Levels Using the USLE Method}

The results of the analysis of five parameters namely rainfall erosivity factor, soil erodibility factor, Terrain factors: Length and slope factor (LS), Land cover or vegetation factor, Conservation practices factor are modeled overlapping map in the study area used the software ArcGIS 10.3. Data processing is performed using Microsoft excel software. Each parameter of the method has a value of the soil erosion rate from the product of all factors. The greater the value of the erosion rate, the value of the erosion hazard level is also higher.

\subsubsection{Rainfall Erosivity Factor $(R)$}

Rainfall erosivity factor demonstrates the kind of erosion triggered by runoff and rainfall on the soil surface of a particular region. Rainfall data were collected from Sleman region operated by department Statistic Meteorology Sleman Yogyakarta. The monthly rainfall average of 10 years (2008-2018) so that it was calculated with an average rainfall erosivity value of $1989 \mathrm{~cm} /$ years. In the literature (Mujiharjo,1989) to determine the magnitude of the rain aggressiveness index could use the formula as follow:

$$
R=2,21 P 1,36
$$

where: $R=$ erosivity Index; $P=\operatorname{runoff}(\mathrm{cm})$. 


\subsubsection{Soil Erodibility Factor $(K)$}

The soil erodibility factor is the value of soil sensitivity which is easy or not the soil experiences erosion. The amount of the soil erodibility value is determined by soil texture/grain size (M), organic content in the soil, soil structure, and soil permeability. The average value of soil texture $(\mathrm{M})$ is based on the percentage $(\%)$ of dust, sand, and clay seen from the results of laboratory testing. Soil structure values are obtained from the soil structure class table, soil permeability properties and organic content values obtained from the laboratory test result, so that average value $(\mathrm{K})$ from the laboratory teste result is 0,33 . This $\mathrm{K}$ value is strongly influenced by the type of soil in the study area. The soil types affect the structure, texture, soil permeability, and organic content. This is indicated by the higher $\mathrm{M}$ value the greater the soil erodibility value ( $\mathrm{K}$ value) and the greater amount of soil erosion that occurs.

\subsubsection{Length and Slope Factor $(L S)$}

Length and slope factor (LS) can be calculated using a topographic map of the study area. slope length measurement using ArcGIS software so that the actual slope length in the field is 693 meters. The slope of the slope is searched by the equation: $\mathrm{CI}=1 / 2000 \times$ Denominator of the scale and after the actual flat distance value is obtained the topographic height value is divided by the actual flat distance $\times 100 \%$ so that the average value for the slope is $2,8 \%$. The total average value of the length and slope (LS) is 1,3 and for Maps of slop can be seen in Fig. 4 while Maps of land use can be seen in Fig. 5.

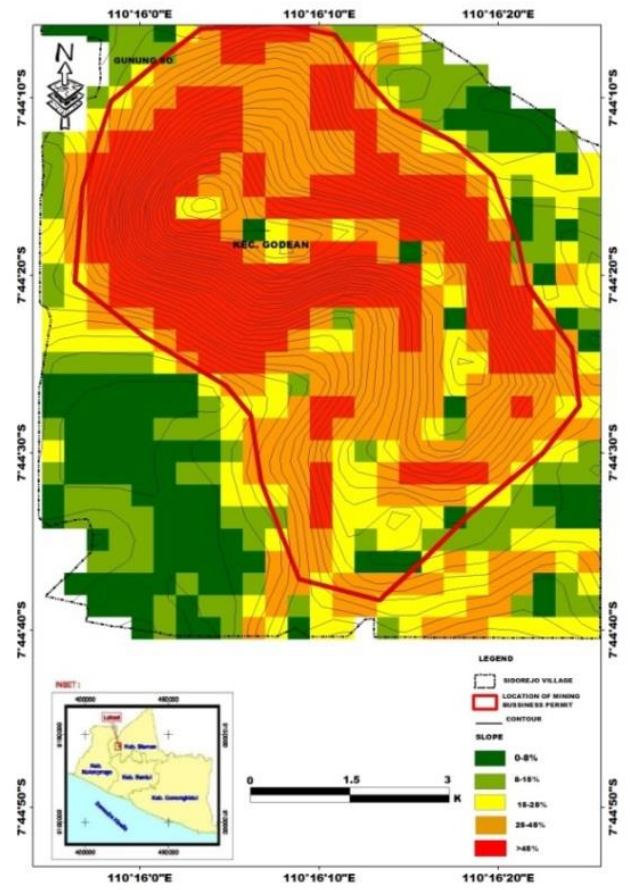

Fig. 4. Slope Map.

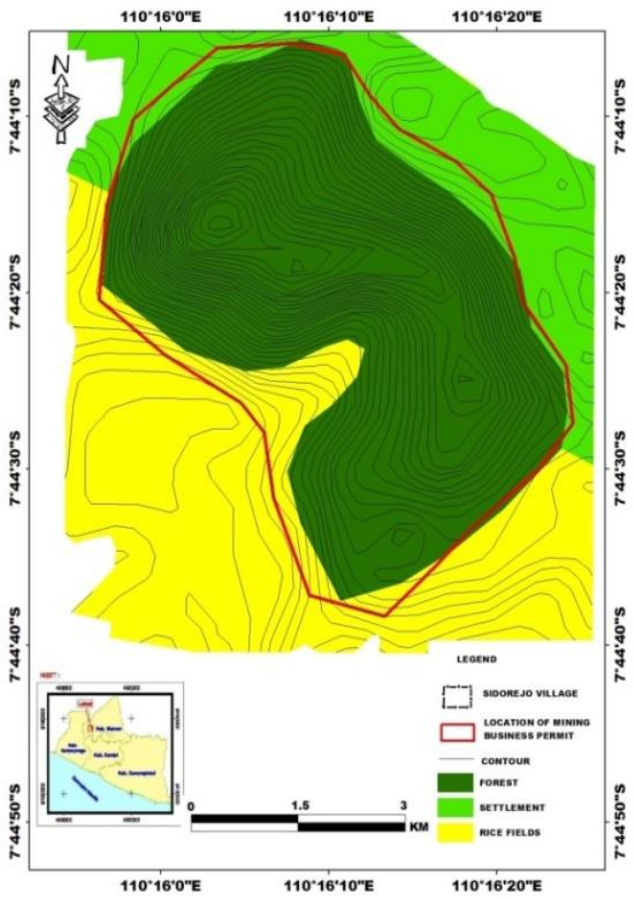

Fig. 5. Land Use Map (Authors). 
The slope is one of the factors that influence erosion. The slope in the study area ranges from $0-45 \%$. It can be shown in Fig. 4 that is dark green with a slope percentage of $0-8 \%$ being on a gentle slope, light green with a slope percentage of $8-15 \%$ on a slightly sloping slope, yellow with a slope percentage of $15-25 \%$ is on a steep slope, and the color is red and light orange brown with the percentage of slopes $25-45 \%$ and $>45 \%$ is a very steep slope. Land use in the study area includes forests, fields and rice fields. In Fig. 5, it can be shown that the yellow color is a rice field that is in a flat area, dark green is a forest that is on a steep slope and the land is being managed by the company as an area of clay material mining. and the light green color is a moor area that is in a sloping area.

\subsubsection{Vegetation Factor $(C)$}

Vegetation factors in the study area are the paddy field, open land without plants, and dry field. Research is done by direct observation in the field and then matched the criteria of the land conservation index table so that an average value of 0,6 was obtained.

\subsubsection{Conservation Practices Factor $(P)$}

The land management factor at the study area was carried out by direct observation in the field then matching the criteria of the land conservation index table so that an average value of 0,7 was obtained. Land conservation techniques consist of traditional bench terraces and no action on land conservation.

\subsection{Soil Erosion Rate Analysis}

Soil erosion rates can be calculated through estimation using the Universal Soil Loss Equation (USLE) Method. So the average erosion rate can be calculated in 358,3 tons / ha / year. The Overlay control (overlay.mbx) allows the merging of layers; the superposition is made by combining databases of thematic layers and the result is the creation of a new database (Bouhata et al., 2014), Bouhata, R. (2008), (Benabderrahmane \& Chenchouni, 2010). All geographic data are integrated and processed in a GIS system using the software ArcGIS 10.3. For overlapping maps can be seen in Fig. 6.

The level of erosion hazard that occurs mostly occurs in the mine area because the area has less vegetation due to mining activities so that soil erosion is easier to occur. In Fig. 6 it can be shown that the dark color is a very heavy level of erosion, red indicates a level of severe erosion, yellow indicates a moderate level of

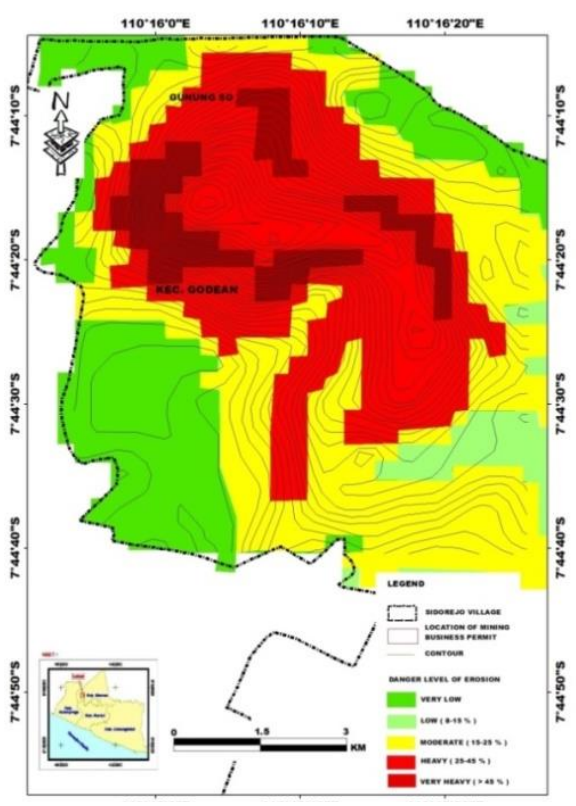

Fig. 6. Map of Erosion Hazard Level. erosion, dark green indicates a mild level of erosion and light green color indicates a very mild level of erosion. A very heavy and heavy level of erosion is present in the mining area. 


\subsection{Land Conservation Priority}

Conservation priorities given based on the class of erosion hazard level include:

- First priority is given to areas that fall into the class of very heavy erosion hazard levels and conservation actions must be taken as soon as possible to reduce soil erosion and even more heavy land damage.

- Second priority is given to areas that fall into the class heavy erosion hazard class and must receive serious attention so that land resources remain sustainable and there is no further damage to land

- Third priority is given to areas that fall into the class moderate erosion hazard class.

- Four priorities are given to areas that fall into the class low erosion hazard class and last priority is given to areas that fall into the class very low erosion hazard class.

\section{CONCLUSION}

The results of estimating the rate of soil erosion with the USLE method produce five classes of soil erosion rates namely $30 \%$ very heavy erosion rate, $5 \%$ heavy erosion rate, $25 \%$ moderate erosion rate, $10 \%$ low erosion rate and $30 \%$ very low erosion rate. Land that very heavy grade erosion value is by planting peanut plants, Land that heavy grade erosion value is by planting sugarcane, Land that moderate grade erosion value is by planting corn and sweet potato plants, Land that very low and low-grade erosion value is by planting corn and rice plants. For all plants that recommended to be planted because they can add nitrogen from the air and remaining crop, can be used as organic materials, can absorb water, the soil in an effort to increase soil fertility and erosion can also improve soil structure.

\section{ACKNOWLEDGMENTS}

The author acknowledges for Mining Engineering UPN Yogyakarta and UPN "Veteran" Yogyakarta that provided the opportunity to write papers.

\section{R E F E R E N C E S}

Abel, W., Gilson Filho, M., José, R.S., José, P. \& José, L.S. (2005) Determinação de Fatores da Equação Universal de Perda de Solo em Sumé, Pb. Revista Brasileira De Engenharia Agrícola e Ambiental, 9(2).

Ananta, K. (1987) Conservation of Land and Water Resources. Kalam Majesty. Jakarta.

Arsyad, S. (1989) Soil and Water Conservation. Bogor Press Institute of Agriculture, Bogor.

Asdak, C. (1995) Hidrology and Management of watersheds. Yogyakarta: Gajah Mada University Press.

Bouhata R., Kalla M. (2014) Mapping of Environmental Vulnerability of Desertification by adaptation of Medalus method in the Endoreic Area of Gadaine (Eastern Algeria). Geographia Technica, 9 (2), 1- 8.

Bouhata, R. (2008) Analyse de la dynamique des sebkhas et son impact sur la vulnérabilité au risque d'inondation dans les dépressions endoréiques situées entre Zana et Madghassen à l'aide de l'imagerie satellitaire LANDSAT. Mémoire de Magister- Iniversité Hadj Lakhdar Batna, 160. 
Benabderrahmane, M.C., \& Chenchouni, H. (2010) Assessing Environmental Sensitivity Areas to Desertification in Eastern Algeria using Mediterranean Desertification and Land Use“MEDALUS" Model. Journal of Sustainable Water \& Environmental Systems, 1 (1), 5-10. DOI: 10.5383/swes.01.01.002

Baver L.D, Gardner, \& John W. (1972) Soil Physics. New York

Cerdan, O., Govers, G., Le Bissonnais, Y., Van Oost, K., Poesen, J., Saby, N., \& Klik, A. (2010) Rates and spatial variations of soil erosion in Europe: a study based on erosion plot data. Geomorphology, 122(1-2), 167-177.

Chaplot, V., Giboire, G., Marchand, P., \& Valentin, C. (2005). Dynamic modelling for linear erosion initiation and development under climate and land-use changes in northern Laos. Catena, 63(23), 318-328.

Da Silva Barros, P. P., Fiorio, P. R., Martins, J. A., \& Demattê, J. A. M. (2016). Comparação entre o uso e ocupação e perda de solo, nos anos de 1995 e 2010, na microbacia hidrográfica do Ceveiro. Revista Ambiência, 12 (2), 513-523

Directorate General of Plantations. (2014) Indonesian Plantation Statistics, Sugar Cane Community, Jakarta.

Da Cruz D.C., Benayas J.M.R., Ferreira G.C., Monteiro A.L., Schwartza G. (2019) Evaluation of Soil Erosion process and conservation practices in the Paragominas- Pa Municipatly (Brazil). Geographia Technica, 14 (1), 14 - 35.

Fiorio, P. R., da Silva Barros, P. P., de Oliveira, J. S., \& Nanni, M. R. (2016). Estimativas de perda de solo em ambiente SIG utilizando diferentes fontes de dados topográficos Estimates of soil loss in a GIS environment using different sources of topographic data. AMBIÊNCIA, 12(1), 203-216

Gardner F., Pearce, R. B, and Mitchellem R.L. (1991) Cultivation of Plant Physiology. Journals University of Indonesia Publisher, Jakarta.

Rifky M., Muhammad F. \& Maryono, (2016) Study of Erosion and Sediment Result for Land Conservation DAS Kreo Hulu. Journal of development Region and City, 12 (4), 429-445.

Indonesianto, Y. (2008). Environmentally Friendly Mining. Yogyakarta.

Irimus I.A., Rosca L., Rus M.I, Mariam F.L., \& Belasco, F., (2017) Landslide Susceptibility Assesment in Almas Basin by Means of the Frequency Rate and GIS Techniques. Geographia Technica, 12 (2), 97 - 109.

Ministry of Forestry. (1998) Decree of the Minister of Forestry and Plantation Number 677 / Kpts-II / 1998. About Community Forests. Ministry of Forestry, Jakarta

Mujiharjo, S. (1989). Monthly rain Erosivity index Bols dan Lenvain kuro Tidur Bengkulu and comparison to EI30 Bols, University Bengkulu, 150-190.

Morgan, R.P.C. (1974) Estimation Regional Variations in soil erosion hazard in Peninsular Malaysia. Journal Technica, 28, 94-106.

Verheijen, F. G., Jones, R. J., Rickson, R. J., \& Smith, C. J. (2009) Tolerable versus actual soil erosion rates in Europe. Earth-Science Reviews, 94(1-4), 23-38.

Wischmeier, W.H. and Smith D.D. (1978) Predicting Rainfall Erosion Losses - A Guide to Conservation Planning. US Department of Agriculture. 